Article

\title{
Chemical Transformations in Proto-Cytoplasmic Media. Phosphorus Coupling in the Silica Hydrogel Phase
}

\author{
Ian B. Gorrell, Timothy W. Henderson, Kamal Albdeery, Philip M. Savage and Terence P. Kee *
}

School of Chemistry, University of Leeds, Woodhouse Lane, Leeds LS2 9JT, UK; I.B.Gorrell@leeds.ac.uk (I.B.G.); timhenderson879@gmail.com (T.W.H.); cmka@leeds.ac.uk (K.A.); sav1415@hotmail.co.uk (P.M.S.)

* Correspondence: t.p.kee@leeds.ac.uk; Tel.: +44-113-343-6421

Received: 7 August 2017; Accepted: 27 October 2017; Published: 19 November 2017

\begin{abstract}
It has been proposed that prebiotic chemical studies on the emergence of primitive life would be most relevant when performed in a hydrogel, rather than an aqueous, environment. In this paper we describe the ambient temperature coupling of phosphorus oxyacids [Pi] mediated by $\mathrm{Fe}(\mathrm{II})$ under aerobic conditions within a silica hydrogel (SHG) environment. We have chosen to examine SHGs as they have considerable geological precedence as key phases in silicification en route to rock formation. Following a description of the preparation and characterization studies on our SHG formulations, coupling experiments between Pi species are described across multiple permutations of (i) Pi compound; (ii) gel formulation; (iii) metal salt additive; and (iv) pH-modifying agent. The results suggest that successful Pi coupling, indicated by observation of pyrophosphate $[\mathrm{PPi}(\mathrm{V})]$ via ${ }^{31} \mathrm{P}-\mathrm{NMR}$ spectroscopy, takes place when the following components are present: (i) a mixture of mixture of $\mathrm{Pi}(\mathrm{III})$ and $\mathrm{Pi}(\mathrm{V})$ or pure $\mathrm{PPi}(\mathrm{III}-\mathrm{V})$; (ii) $\mathrm{Fe}(\mathrm{II})$; (iii) acetic or formic acid (not hydrochloric acid); (iv) aerobic conditions or the presence of $\mathrm{H}_{2} \mathrm{O}_{2}$ as an oxidant; and (v) the presence of a gel system. On the basis of these, and aqueous control reactions, we suggest mechanistic possibilities.
\end{abstract}

Keywords: silica; hydrogel; phosphorus; coupling; prebiotic

\section{Introduction}

Within the field of abiogenesis, significant advances have been made in many chemical, prebiotic directions, including synthetic routes to peptides [1-8], nucleic acid monomers [9-12] and subsequent oligomerization [13-15], proto-cellular assemblies [16-20] and proto-bioenergetic systems [21-25]. In all of these processes, one is manipulating systems that lie far from equilibrium in either a structural and/or dynamic sense [25]. In many cases, success requires control over local water activity [26] via, for example, wetting-drying cycles [7], non-aqueous media [27], and interaction with mineral surfaces [28] or frozen ice media [29].

It is envisaged that local environments in which the most primitive living systems may have emerged would have possessed properties that permitted, at least, the following functions: (i) molecular ingress and egress; (ii) water activity modulation; (iii) catalysis of chemical processes; (iv) a barrier between internal and external matrix; and (v) the ability to hold charge and concentration gradients [30]. However, observations and suggestions made by Trevors and Pollack over several years [31-36], in an attempt to provide a new perspective on the above boundary conditions, provide an interesting angle on origin of life studies. If one is trying to understand the emergence of the simplest form of biological life on Earth, that form being commonly referred to as LUCA, the Last Universal Common Ancestor [37], then it is arguably logical to envisage that the internal environment of LUCA might closely resemble the internal milieu of simple bacteria and archea. A cellular interior is not simply aqueous, nor is it simply a salt-water solution. It is best viewed as a hydrogel, a molecularly crowded, 
water-filled, cytoplasmic environment which is supported by some polymer or polymer-composite matrix with the ability to alter molecular diffusion, polymer structure and potentially, chemical reactivity [31-36]. Furthermore, a hydrogel is capable of maintaining physical integrity without the need for a membrane, providing a natural ability to exclude solutes according to their size. Thus, valuable charge and ion gradients, capable of being exploited for the transduction of energy [38], can be maintained naturally across a gel material without rapid dissipation. Moreover, recognition of the importance of molecular crowding within cellular gel-type environments as influencing aqueous structure and properties on the micro-scale [39-41] is a well-established phenomenon in biology. Whilst there has been clear recognition of the importance of a molecularly crowded environment to biological processes, attempts to translate that into an early Earth, prebiotic environment without compartmentalization have led to mixed results. For example, whilst two-phase and coacervate systems have long been proposed as effective membrane-free protocellular models [42-44], Szostak and co-workers found that they did not always provide effective segregation of molecular components [45].

We recognize the potential significance of a gel environment, especially in terms of selectively concentrating molecular building blocks [45], modifying water activity [35], influencing molecular diffusivity and hence residence time within the gel [34], manipulating molecular conformation of macromolecules and affecting the course of chemical reactions either thermodynamically in terms of product speciation or kinetics [39]. The question for us, then, was this: what form of hydrogel environment should one be looking at in order to be as prebiotically relevant as possible? Our response to this question was to consider geologically established environments based on silica hydrogels (SHGs) [46-48].

We have, therefore, embarked on a series of studies designed to explore differences between the outcomes of certain chemical processes when performed in the silica hydrogel phase as opposed to the aqueous phase. In doing so we have not attempted to mimic a specific, known geological silica gel deposit, but to focus on how certain processes may be influenced when the phase is changed from aqueous to hydrogel In this paper we explore the coupling of phosphorus (P) oxyacids to afford condensed phosphate oxyacids, specifically pyrophosphate $\mathrm{PPi}(\mathrm{V})$. Condensed P-species are ubiquitous energy currency molecules in contemporary biochemistry, for example the nucleotide triphosphates (Figure 1). Various, chemically less complex condensed P-species have been proposed to have been plausibly available to drive prebiotic chemistry. The latter include pyrophosphate [PPi(V)] [49-51], cyclo-trimetaphosphate (c-TMP) [52-54] and pyrophosphite [PPi(III)] (all of which contain the P-O-P linkage; Figure 1) [55-57]. However, the coupling of mono-phosphorus species to condensed P-compounds is usually observed to take place under conditions which are either thermally forcing [58], wet-dry cycles [59] or in the presence of activating agents [60]. In this paper, we demonstrate that aqueous phase mixtures of $\mathrm{Pi}(\mathrm{V})\left(\mathrm{H}_{2} \mathrm{PO}_{4}{ }^{-}\right)$and $\mathrm{Pi}(\mathrm{III})\left(\mathrm{H}_{2} \mathrm{PO}_{3}{ }^{-}\right)$which do not ordinarily undergo condensation to afford $\mathrm{PPi}(\mathrm{V})$ under ambient temperature conditions, do indeed do so when incubated within a silica hydrogel environment. Moreover, we examine possible mechanisms for such coupling and provide a plausible modus operandi for the gel-phase composite to undergo condensation. We have chosen to examine the role of $\mathrm{Pi}(\mathrm{III})$ in this study as it is the $\mathrm{P}$-compound with which we have worked most often. However, reduced P-compounds are rare in contemporary biology and alternative methods for mobilizing, activating and coupling P-species have been proposed, see $[49-54,60]$ and references therein.
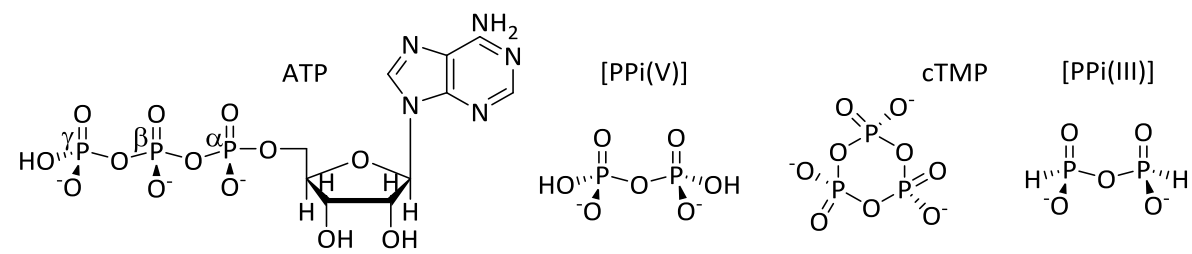

Figure 1. Representative phosphorus(P)-based energy currency molecules used in contemporary biology (adenosine triphosphate, ATP) along with suggested prebiotic equivalents [PPi(V)], cTMP \& [PPi(III)]. 


\section{Materials and Methods}

Monosodium orthophosphate $\left(\mathrm{NaH}_{2} \mathrm{PO}_{4}\right)$ and monosodium phosphite $\left(\mathrm{NaH}_{2} \mathrm{PO}_{3}\right)$ were either commercial samples or were prepared by treating appropriate solutions of orthophosphoric acid or orthophosphorous acids (purchased from Sigma-Aldrich, Gillingham, UK) with equimolar amounts of sodium hydroxide (from Fisher Scientific, Loughborough, UK) in purified water at ambient temperature. Isohypophosphate [PPi(III-V)] was prepared according to the published method [56] and was composed of a mixture comprising $[\mathrm{PPi}(\mathrm{III}-\mathrm{V})]-[\mathrm{Pi}(\mathrm{III}) / \mathrm{Pi}(\mathrm{V})]$ in the relative proportions: $44-56 \%$ respectively (Figure S1, Supplementary Materials). All water used herein was ultra-pure deionized water prepared using the Purite Select Analyst deionization system. Sodium silicate solution was commercial (from Merck KGaA, Darmstadt, Germany) and contained ( $\leq 27 \% \mathrm{SiO}_{2}$ and $\leq 10 \%$ $\mathrm{NaOH})$. Hydrochloric acid, silica gel $\left(\mathrm{GF}_{254}\right)$, hydrogen peroxide $\left(\mathrm{H}_{2} \mathrm{O}_{2}\right)$, glacial acetic acid, formic acid and metal salts $\left(\mathrm{FeCl}_{2} \cdot 4 \mathrm{H}_{2} \mathrm{O} ; \mathrm{FeSO}_{4} \cdot 7 \mathrm{H}_{2} \mathrm{O} ; \mathrm{Fe}\left(\mathrm{NO}_{3}\right)_{3} \cdot 9 \mathrm{H}_{2} \mathrm{O} ; \mathrm{CuSO}_{4} \cdot 5 \mathrm{H}_{2} \mathrm{O} ; \mathrm{MgCl}_{2}\right)$ were commercial samples (from Fisher, Riedel de Haën, Seelze, Germany; Aldrich, Fluka, Buchs, Switzerland or Merck KGaA, Darmstadt, Germany) and were used as received.

\subsection{Analytical Methods}

Critical-point drying (CPD) was performed using a Polaron 3100 CPD instrument. Samples of silica hydrogel (prepared according to the procedure described in Section 2.2 below) were prepared inside $3.5 \mathrm{~cm}$ length $(1.0 \mathrm{~cm}$ OD neck) plastic cuvettes, the lids of which had been punctured with 3-4 small needle holes. The gels were then incubated with acetone to remove the water and then transferred to fresh acetone in the CPD instruments boat. This was loaded into the CPD, where the acetone was replaced with liquid $\mathrm{CO}_{2}$ with multiple flushes over the space of $1 \mathrm{~h}$. Subsequently, the system was heated to $35^{\circ} \mathrm{C}$ via the attached thermo-regulator water system for ca $30 \mathrm{~min}$, until the critical pressure of $1200 \mathrm{psi}$ had been reached. At this point, the system $/ \mathrm{CO}_{2}$ gas was vented to allow the dried samples to be removed. Sample matrices dried thus were analyzed via scanning electron microscopy as outlined below. Samples were dialyzed prior to SEM analysis by incubation in sealed dialysis tubing in ultra-pure deionized water for a period of four days.

Scanning electron microscopy was performed in the School of Chemistry, using an FEI Nova NanoSEM 450 instrument operating at $3 \mathrm{kV}$ or $18 \mathrm{kV}$ for EDX. Samples were iridium-coated prior to viewing and were inserted into the sample chamber under high vacuum $\left(6.3 \times 10^{-6}\right.$ Torr $)$. The image magnification varied from $100 \mathrm{~nm}$ to $1 \mu \mathrm{m}$ with high-resolution images collected in the secondary electron mode. Element analysis (EDX) was performed using AMETEK software TEME V 3.4 and surface-area measurements were made using a Micrometrics ASAP2020 physisorption platform and the Brunauer-Emmett-Teller method. Samples was degassed for a period of no less than $3 \mathrm{~h}$ at $120^{\circ} \mathrm{C}$ before measurements were made.

Samples of SHG's ( $4 \mathrm{~mL}$ ) were prepared directly in a disposable cuvette, as described in Section 2.2 below, and sealed directly after being prepared, then inserted in a Malvern Zetasizer Nano ZSP (Great Malvern, UK) model for average particle size measurements using the technique of dynamic light-scattering. The instrument was calibrated for a period of $120 \mathrm{~s}$ with a refractive index of water and a measurement angle of $173^{\circ}$ back scatter at ambient temperature and set to collect readings every $600 \mathrm{~s}$.

NMR spectra were recorded in $5 \mathrm{~mm}$ tubes on a Bruker Avance III 300 spectrometer operating at $121.495 \mathrm{MHz}$ for ${ }^{31} \mathrm{P}$, using $\mathrm{D}_{2} \mathrm{O}$ or a $\mathrm{D}_{2} \mathrm{O}$-containing capillary to provide the lock signal. NMR analyses were performed with both a $3 \mathrm{~s}$ pulse delay and in a gated ${ }^{1} \mathrm{H}$ coupled mode in order to limit any nuclear Overhauser effects which could compromise integration measurements. In each case, 320 transients were obtained. $\mathrm{pH}$ measurements were made using a Jenway $350 \mathrm{pH}$ meter (Spectronic Instruments, Leeds, UK) connected to an $\mathrm{Ag} / \mathrm{AgCl}$ micro electrode (Aldrich) on samples in $2 \mathrm{~mL}$ glass vials; calibrations were performed using Buffer tablets at $\mathrm{pH} 4$ (phthalate) and 7 (phosphate) supplied by Fisher. 


\subsection{Preparation of Silica Hydrogels (SHGs)}

A standard operating protocol (SOP) for the production of SHGs was afforded by combining two solutions: (A) a solution of $360 \mu \mathrm{L}$ glacial acetic acid diluted by addition of $7600 \mu \mathrm{L}$ of ultra-pure deionized water, and (B) 1250,2500 and $3750 \mu \mathrm{L}$ respectively of a sodium silicate solution $\left(\leq 27 \% \mathrm{SiO}_{2}\right.$ and $\leq 10 \% \mathrm{NaOH}$ ), diluted to $8000 \mu \mathrm{L}$ with ultra-pure deionized water [61]. These compositions afford three different gels, which we identify as $0.5,0.75$ and $1.0 \mathrm{M}$ silica, respectively, (the calculation is available as part of the SI). The sodium silicate solution was subsequently poured into the acid solution in a test tube. The tube was sealed and then inverted slowly (shaking the tube must be avoided) several 3-5) times to mix the components thoroughly, and then allowed to stand until gelation had been observed to take place. The gelation process that took place in the tube was confirmed by the onset of slight turbidity and inversion of the tube, which revealed the stability towards gravity of the gel (Figure 2b). SHGs were prepared using this procedure with (i) ultra-pure deionized water as outlined above; and (ii) with a salt-water substitute, standard mean ocean water (SMOW) from which the iron component had been removed [62].

a

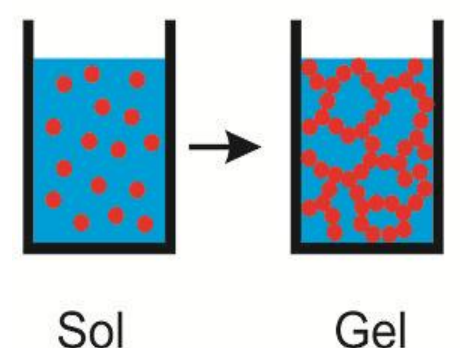

b

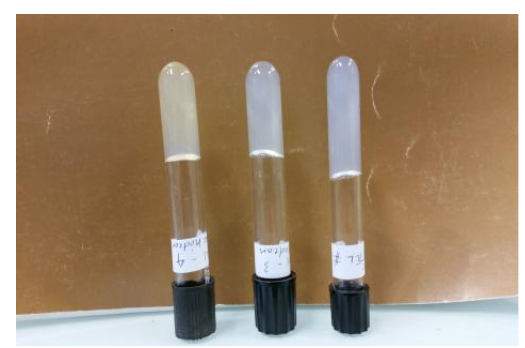

Figure 2. (a) Sol-to-gel phase transition. Crossed linked polymerization of building blocks affords structural integrity to what is otherwise a solvent-rich system; (b) examples of silica hydrogels. These hydrogels, produced using the method outlined in the Experimental section (vide infra), demonstrate the mechanical stability of the system under gravity. The three different samples contain the same quantity of silicate but different salt-compositions in water.

\subsection{General Methods for Preparing and Analyzing Phosphorus-Implanted SHGs}

Gels were prepared as described above using the following quantities: sodium silicate solution $(1200 \mu \mathrm{L})$, acid (400 $\mu \mathrm{L}$ either acetic or formic), ultra-distilled water or a modification of standard mean ocean water (SMOW-lite [62] which did not contain additional iron; $6600 \mu \mathrm{L}$ ). Within these basic gels, variants were prepared containing phosphorus (Pi) additives $(1000 \mu \mathrm{L}$ at $0.5 \mathrm{M}$, each component added to the acid phase of the gel system, see Table 1 ) and appropriate metal salts (25, $100 \mathrm{or} 250 \mathrm{mg}$, Table 2) either layered on the gel post-preparation or dissolved in the acid phase prior to gel-phase formation. Reaction systems were left usually for a period of $72 \mathrm{~h}$ under ambient temperature conditions (between $20-22{ }^{\circ} \mathrm{C}$ ) unless noted otherwise [Table 2 entries G1-28 (G for gel)]. For analysis, the gel was destroyed first by raising the $\mathrm{pH}$ upon stirring with $5 \mathrm{M}$ sodium hydroxide solution $(6 \mathrm{~mL})$ which also resulted in precipitation of metal salts. The system was then centrifuged to compress the salts, filtered, and the water removed from the filtrate at $77 \mathrm{~K}$ by freeze-drying. The residue was then extracted into $\mathrm{D}_{2} \mathrm{O}$ $(0.5 \mathrm{~mL})$ prior to analysis via ${ }^{31} \mathrm{P}-\mathrm{NMR}$ spectroscopy. Any observation of pyrophosphate being present was quantified according to the percentage of total $\mathrm{P}$ in the extracted $\mathrm{D}_{2} \mathrm{O}$. In control experiments, we confirmed that a sample of pyrophosphate $[\mathrm{PPi}(\mathrm{V})]$ remained unchanged in the presence of sodium hydroxide for a period significantly exceeding the necessary analysis time. All experiments were run in triplicate unless stated otherwise and the range of values returned indicated. Given the heterogeneous nature of the gel systems we find the spread of values to be rather larger, proportionately, than might be the case in solution experiments. 
Table 1. Component matrix for additives to basis silica hydrogel formulation.

\begin{tabular}{ccccc}
\hline Solvent Systems & Water & $\begin{array}{c}\text { Standard mean ocean } \\
\text { water (SMOW) }\end{array}$ & & \\
\hline $\begin{array}{c}\text { Phosphorus (Pi) } \\
\text { Components }\end{array}$ & $\begin{array}{c}1: 1 \text { molar } \mathrm{Pi}(\mathrm{V}) \& \\
\mathrm{Pi}(\mathrm{III})(0.5 \mathrm{M} \text { each })\end{array}$ & $\mathrm{Pi}(\mathrm{III})(0.5 \mathrm{M})$ & $\mathrm{Pi}(\mathrm{V})(0.5 \mathrm{M})$ & $\mathrm{PPi}(\mathrm{III}-\mathrm{V})(0.5 \mathrm{M})$ \\
\hline Metal Additives & $\mathrm{Fe}(\mathrm{II})$ & $\mathrm{Fe}(\mathrm{III})$ & $\mathrm{Cu}(\mathrm{II})$ & $\mathrm{Mg}(\mathrm{II})$ \\
\hline Acid Components & Acetic acid & Formic acid & $\begin{array}{c}\text { Hydrochloric } \\
\text { acid }\end{array}$ & \\
\hline
\end{tabular}

Table 2. Summary of experiment library. $a$ : $1 \mathrm{M} \mathrm{NaOH}$ extraction; $b$ : $5 \mathrm{M} \mathrm{NaOH}$ extraction; $c$ : $0.28 \%$ yield after $72 \mathrm{~h}$; $d$ : System maintained at $50{ }^{\circ} \mathrm{C}$; $e$ : Work up after 9 days; $f$ : In presence of air; $g$ : In presence of $\mathrm{H}_{2} \mathrm{O}_{2}(1 \mathrm{~mL}, 0.2 \mathrm{M}) ; 0.5 \mathrm{M}$ silica hydrogel; $h$ : In presence of $\mathrm{H}_{2} \mathrm{O}_{2}(1 \mathrm{~mL}, 0.2 \mathrm{M}) ; 1.0 \mathrm{M}$ silica hydrogel; $i$ : In presence of $\mathrm{H}_{2} \mathrm{O}_{2}(1 \mathrm{~mL}, 0.2 \mathrm{M}) ; 1.5 \mathrm{M}$ silica hydrogel; $j$ : $0.5 \mathrm{M}$ silica hydrogel; $\mathrm{H}_{2} \mathrm{O}_{2}(1 \mathrm{~mL}, 0.2 \mathrm{M})$ no $\mathrm{Fe}(\mathrm{II}) ; k$ : $1.0 \mathrm{M}$ silica hydrogel; $\mathrm{H}_{2} \mathrm{O}_{2}(1 \mathrm{~mL}, 0.2 \mathrm{M})$ no $\mathrm{Fe}(\mathrm{II}) ; l: 1.5 \mathrm{M}$ silica hydrogel; $\mathrm{H}_{2} \mathrm{O}_{2}(1 \mathrm{~mL}, 0.2 \mathrm{M})$ no $\mathrm{Fe}(\mathrm{II}) ; m$ : Sample not gelled; $n$ : Single measurement; $o$ : Solution phase; no gel, aerobic; $p$ : Solution phase; no gel; $\mathrm{H}_{2} \mathrm{O}_{2}(1 \mathrm{~mL}, 0.2 \mathrm{M})$; q: Solution phase; presence of GF254 (0.2 g). N/O signifies not observed.

\begin{tabular}{|c|c|c|c|c|c|c|c|c|}
\hline Sample & Solvent & Acid & Pi Compounds & $\begin{array}{c}\text { Metal } \\
\text { Additives }\end{array}$ & $\begin{array}{l}\text { Additive } \\
\text { Delivery }\end{array}$ & Mass (g) & $\operatorname{PPi}(\mathrm{V})(\%)$ & \\
\hline G1 & $\mathrm{H}_{2} \mathrm{O}$ & $\mathrm{MeCO}_{2} \mathrm{H}$ & 1:1 PPi(III)-Pi(V) & $\mathrm{Fe}(\mathrm{II})$ & Deposited & 25 & 0.30 & $a$ \\
\hline $\mathrm{G} 2$ & $\mathrm{H}_{2} \mathrm{O}$ & $\mathrm{MeCO}_{2} \mathrm{H}$ & 1:1 PPi(III)-Pi(V) & $\mathrm{Fe}(\mathrm{II})$ & Deposited & 25 & 0.47 & $b$ \\
\hline G3 & $\mathrm{H}_{2} \mathrm{O}$ & $\mathrm{MeCO}_{2} \mathrm{H}$ & 1:1 PPi(III)-Pi(V) & $\mathrm{Fe}(\mathrm{II})$ & Solution & 25 & 0.10 & $c$ \\
\hline G4 & $\mathrm{H}_{2} \mathrm{O}$ & $\mathrm{MeCO}_{2} \mathrm{H}$ & 1:1 PPi(III)-Pi(V) & $\mathrm{Fe}(\mathrm{II})$ & Deposited & 25 & 0.21 & \\
\hline G5 & $\mathrm{H}_{2} \mathrm{O}$ & $\mathrm{MeCO}_{2} \mathrm{H}$ & 1:1 PPi(III)-Pi(V) & $\mathrm{Fe}(\mathrm{II})$ & Deposited & 25 & 0.10 & \\
\hline G6 & $\mathrm{H}_{2} \mathrm{O}$ & $\mathrm{MeCO}_{2} \mathrm{H}$ & 1:1 PPi(III)-Pi(V) & $\mathrm{Fe}(\mathrm{II})$ & Deposited & 25 & 0.23 & $d$ \\
\hline G7 & $\mathrm{H}_{2} \mathrm{O}$ & $\mathrm{MeCO}_{2} \mathrm{H}$ & 1:1 PPi(III)-Pi(V) & $\mathrm{Fe}(\mathrm{II})$ & Solution & 250 & 0.66 & \\
\hline G8 & $\mathrm{H}_{2} \mathrm{O}$ & $\mathrm{MeCO}_{2} \mathrm{H}$ & 1:1 PPi(III)-Pi(V) & $\mathrm{Fe}(\mathrm{II})$ & Deposited & 250 & 0.40 & \\
\hline G9 & $\mathrm{H}_{2} \mathrm{O}$ & $\mathrm{HCO}_{2} \mathrm{H}$ & 1:1 PPi(III)-Pi(V) & $\mathrm{Fe}(\mathrm{II})$ & Deposited & 100 & 0.13 & \\
\hline G10 & $\mathrm{H}_{2} \mathrm{O}$ & $\mathrm{MeCO}_{2} \mathrm{H}$ & 1:1 PPi(III)-Pi(V) & $\mathrm{Fe}(\mathrm{II})$ & Deposited & 100 & 0.55 & $e$ \\
\hline G11 & $\mathrm{H}_{2} \mathrm{O}$ & $\mathrm{MeCO}_{2} \mathrm{H}$ & PPi(III-V) & $\mathrm{Fe}(\mathrm{II})$ & Deposited & 100 & $3.2 \pm 1.0$ & $f$ \\
\hline G12 & $\mathrm{H}_{2} \mathrm{O}$ & $\mathrm{MeCO}_{2} \mathrm{H}$ & PPi(III-V) & $\mathrm{Fe}(\mathrm{II})$ & Deposited & 100 & $2.4 \pm 1.0$ & $f$ \\
\hline G13 & $\mathrm{H}_{2} \mathrm{O}$ & $\mathrm{MeCO}_{2} \mathrm{H}$ & PPi(III-V) & $\mathrm{Fe}(\mathrm{II})$ & Deposited & 100 & $12.6 \pm 0.5$ & $g$ \\
\hline G14 & $\mathrm{H}_{2} \mathrm{O}$ & $\mathrm{MeCO}_{2} \mathrm{H}$ & PPi(III-V) & $\mathrm{Fe}(\mathrm{II})$ & Deposited & 100 & $9.3 \pm 0.5$ & $h$ \\
\hline G15 & $\mathrm{H}_{2} \mathrm{O}$ & $\mathrm{MeCO}_{2} \mathrm{H}$ & PPi(III-V) & $\mathrm{Fe}(\mathrm{II})$ & Deposited & 100 & $5.7 \pm 0.6$ & $i$ \\
\hline G16 & $\mathrm{H}_{2} \mathrm{O}$ & $\mathrm{MeCO}_{2} \mathrm{H}$ & PPi(III-V) & $\mathrm{Fe}(\mathrm{II})$ & Solution & 100 & $20 \pm 5.0$ & $g$ \\
\hline G17 & $\mathrm{H}_{2} \mathrm{O}$ & $\mathrm{MeCO}_{2} \mathrm{H}$ & PPi(III-V) & $\mathrm{Fe}(\mathrm{II})$ & Solution & 100 & $15.6 \pm 3.0$ & $h$ \\
\hline G18 & $\mathrm{H}_{2} \mathrm{O}$ & $\mathrm{MeCO}_{2} \mathrm{H}$ & PPi(III-V) & $\mathrm{Fe}(\mathrm{II})$ & Solution & 100 & $10.7 \pm 0.6$ & $i$ \\
\hline G19 & $\mathrm{H}_{2} \mathrm{O}$ & $\mathrm{MeCO}_{2} \mathrm{H}$ & PPi(III-V) & None & None & 0 & $1.8 \pm 0.4$ & $j$ \\
\hline G20 & $\mathrm{H}_{2} \mathrm{O}$ & $\mathrm{MeCO}_{2} \mathrm{H}$ & PPi(III-V) & None & None & 0 & $1.8 \pm 0.2$ & $k$ \\
\hline G21 & $\mathrm{H}_{2} \mathrm{O}$ & $\mathrm{MeCO}_{2} \mathrm{H}$ & PPi(III-V) & None & None & 0 & $1.3 \pm 0.5$ & $l$ \\
\hline $\mathrm{G} 22$ & $\mathrm{H}_{2} \mathrm{O}$ & $\mathrm{MeCO}_{2} \mathrm{H}$ & PPi(III-V) & $\mathrm{Fe}(\mathrm{II})$ & Deposited & 100 & $\mathrm{~N} / \mathrm{O}$ & $m$ \\
\hline G23 & $\mathrm{H}_{2} \mathrm{O}$ & $\mathrm{HCl}$ & 1:1 PPi(III)-Pi(V) & $\mathrm{Fe}(\mathrm{II})$ & Deposited & 100 & $\mathrm{~N} / \mathrm{O}$ & \\
\hline G24 & $\mathrm{H}_{2} \mathrm{O}$ & $\mathrm{MeCO}_{2} \mathrm{H}$ & 1:1 PPi(III)-Pi(V) & $\mathrm{Fe}(\mathrm{III})$ & Solution & 250 & $\mathrm{~N} / \mathrm{O}$ & \\
\hline G25 & $\mathrm{H}_{2} \mathrm{O}$ & $\mathrm{MeCO}_{2} \mathrm{H}$ & $\operatorname{Pi}(\mathrm{III})$ & $\mathrm{Fe}(\mathrm{III})$ & Solution & 250 & $\mathrm{~N} / \mathrm{O}$ & \\
\hline G26 & $\mathrm{H}_{2} \mathrm{O}$ & $\mathrm{MeCO}_{2} \mathrm{H}$ & $\mathrm{Pi}(\mathrm{V})$ & $\mathrm{Fe}(\mathrm{III})$ & Solution & 250 & $\mathrm{~N} / \mathrm{O}$ & \\
\hline G27 & $\mathrm{H}_{2} \mathrm{O}$ & $\mathrm{MeCO}_{2} \mathrm{H}$ & $\mathrm{Pi}(\mathrm{V})$ & $\mathrm{Fe}(\mathrm{III})$ & Deposited & 25 & $\mathrm{~N} / \mathrm{O}$ & \\
\hline G28 & $\mathrm{H}_{2} \mathrm{O}$ & $\mathrm{MeCO}_{2} \mathrm{H}$ & 1:1 PPi(III)-Pi(V) & $\mathrm{Fe}(\mathrm{III})$ & Deposited & 25 & $\mathrm{~N} / \mathrm{O}$ & \\
\hline G29 & $\mathrm{H}_{2} \mathrm{O}$ & $\mathrm{MeCO}_{2} \mathrm{H}$ & $\operatorname{Pi}(\mathrm{III})$ & $\mathrm{Fe}(\mathrm{III})$ & Deposited & 25 & $\mathrm{~N} / \mathrm{O}$ & \\
\hline G30 & $\mathrm{H}_{2} \mathrm{O}$ & $\mathrm{MeCO}_{2} \mathrm{H}$ & 1:1 PPi(III)-Pi(V) & $\mathrm{Cu}(\mathrm{II})$ & Deposited & 25 & $\mathrm{~N} / \mathrm{O}$ & \\
\hline G31 & $\mathrm{H}_{2} \mathrm{O}$ & $\mathrm{MeCO}_{2} \mathrm{H}$ & 1:1 PPi(III)-Pi(V) & $\mathrm{Cu}(\mathrm{II})$ & Deposited & 100 & $\mathrm{~N} / \mathrm{O}$ & \\
\hline G32 & $\mathrm{H}_{2} \mathrm{O}$ & $\mathrm{MeCO}_{2} \mathrm{H}$ & 1:1 PPi(III)-Pi(V) & $\mathrm{Cu}(\mathrm{II})$ & Deposited & 250 & $\mathrm{~N} / \mathrm{O}$ & \\
\hline G33 & $\mathrm{H}_{2} \mathrm{O}$ & $\mathrm{MeCO}_{2} \mathrm{H}$ & 1:1 PPi(III)-Pi(V) & $\mathrm{Mg}(\mathrm{II})$ & Deposited & 25 & $\mathrm{~N} / \mathrm{O}$ & \\
\hline G34 & $\mathrm{H}_{2} \mathrm{O}$ & $\mathrm{MeCO}_{2} \mathrm{H}$ & 1:1 PPi(III)-Pi(V) & $\mathrm{Mg}(\mathrm{II})$ & Deposited & 100 & $\mathrm{~N} / \mathrm{O}$ & \\
\hline G35 & $\mathrm{H}_{2} \mathrm{O}$ & $\mathrm{MeCO}_{2} \mathrm{H}$ & 1:1 PPi(III)-Pi(V) & $\mathrm{Mg}(\mathrm{II})$ & Deposited & 250 & $\mathrm{~N} / \mathrm{O}$ & \\
\hline G36 & SMOW & $\mathrm{MeCO}_{2} \mathrm{H}$ & 1:1 PPi(III)-Pi(V) & $\mathrm{Fe}(\mathrm{II})$ & Deposited & 250 & 0.80 & $n$ \\
\hline $\mathrm{C} 1$ & $\mathrm{H}_{2} \mathrm{O}$ & $\mathrm{MeCO}_{2} \mathrm{H}$ & 1:1 PPi(III)-Pi(V) & $\mathrm{Fe}(\mathrm{II})$ & Solution & 100 & $\mathrm{~N} / \mathrm{O}$ & $o$ \\
\hline $\mathrm{C} 2$ & $\mathrm{H}_{2} \mathrm{O}$ & $\mathrm{MeCO}_{2} \mathrm{H}$ & PPi(III-V) & $\mathrm{Fe}(\mathrm{II})$ & Solution & 100 & $1.3 \pm 0.5$ & $o$ \\
\hline $\mathrm{C} 3$ & $\mathrm{H}_{2} \mathrm{O}$ & $\mathrm{MeCO}_{2} \mathrm{H}$ & PPi(III-V) & $\mathrm{Fe}(\mathrm{II})$ & Solution & 100 & $35.1 \pm 5.0$ & $p$ \\
\hline $\mathrm{C} 4$ & $\mathrm{H}_{2} \mathrm{O}$ & $\mathrm{MeCO}_{2} \mathrm{H}$ & 1:1 PPi(III)-Pi(V) & $\mathrm{Fe}(\mathrm{II})$ & Solution & 100 & $\mathrm{~N} / \mathrm{O}$ & $p$ \\
\hline C5 & $\mathrm{H}_{2} \mathrm{O}$ & $\mathrm{MeCO}_{2} \mathrm{H}$ & 1:1 PPi(III)-Pi(V) & $\mathrm{Fe}(\mathrm{II})$ & Solution & 100 & $\mathrm{~N} / \mathrm{O}$ & $q$ \\
\hline C6 & $\mathrm{H}_{2} \mathrm{O}$ & $\mathrm{MeCO}_{2} \mathrm{H}$ & PPi(III-V) & $\mathrm{Fe}(\mathrm{II})$ & Solution & 100 & $1.2 \pm 0.5$ & $q$ \\
\hline
\end{tabular}




\subsection{Control Experiments in Aqueous Solution}

The following quantities were employed in the control systems:

C1: $\mathrm{H}_{2} \mathrm{O}(6.6 \mathrm{~mL}), \mathrm{Pi}(\mathrm{III})(0.5 \mathrm{M}), \mathrm{Pi}(\mathrm{V})(0.5 \mathrm{M}), \mathrm{Fe}(\mathrm{II})(100 \mathrm{mg})$, glacial acetic acid (200 $\left.\mu \mathrm{L}\right)$

C2: $\mathrm{H}_{2} \mathrm{O}(6.6 \mathrm{~mL}), \mathrm{PPi}(\mathrm{III}-\mathrm{V})(0.5 \mathrm{M}), \mathrm{Fe}(\mathrm{II})(100 \mathrm{mg})$, glacial acetic acid $(200 \mu \mathrm{L})$

C3: $\mathrm{H}_{2} \mathrm{O}(6.6 \mathrm{~mL}), \mathrm{PPi}(\mathrm{III}-\mathrm{V})(0.5 \mathrm{M}), \mathrm{Fe}(\mathrm{II})(100 \mathrm{mg})$, glacial acetic acid $(200 \mu \mathrm{L}), \mathrm{H}_{2} \mathrm{O}_{2}(1 \mathrm{~mL}, 0.2 \mathrm{M})$

C4: $\mathrm{H}_{2} \mathrm{O}(6.6 \mathrm{~mL}), \mathrm{Pi}(\mathrm{III})(0.5 \mathrm{M}), \mathrm{Pi}(\mathrm{V})(0.5 \mathrm{M}), \mathrm{Fe}(\mathrm{II})(100 \mathrm{mg})$, glacial acetic acid $(200 \mu \mathrm{L}), \mathrm{H}_{2} \mathrm{O}_{2}(1 \mathrm{~mL}$, $0.2 \mathrm{M})$

C5: $\mathrm{H}_{2} \mathrm{O}(6.6 \mathrm{~mL}), \mathrm{Pi}(\mathrm{III})(0.5 \mathrm{M}), \mathrm{Pi}(\mathrm{V})(0.5 \mathrm{M}), \mathrm{Fe}(\mathrm{II})(100 \mathrm{mg})$, glacial acetic acid (200 $\left.\mu \mathrm{L}\right)$, silica gel $\mathrm{GF}_{254}(0.2 \mathrm{~g})$

C6: $\mathrm{H}_{2} \mathrm{O}(6.6 \mathrm{~mL}), \mathrm{PPi}(\mathrm{III}-\mathrm{V})(0.5 \mathrm{M}), \mathrm{Fe}(\mathrm{II})(100 \mathrm{mg})$, glacial acetic acid $(200 \mu \mathrm{L})$, silica gel $\mathrm{GF}_{254}(0.2 \mathrm{~g})$.

\section{Results}

\subsection{Preparation and Analysis of SHGs}

A hydrogel may be considered to result from the polymerization of molecular building blocks which results in a three-dimensional, macromolecular network providing some level of structural rigidity but also encapsulating significant quantities of water (Figure 2a) [63]. In the case of SHGs, this network results from silica formation either by $\mathrm{pH}$ modification of an alkaline solution of sodium silicate [64], or via sol-gel processing of organosilicate esters [65]. In this work we have selected to work with the former formulation mechanism as it appears to afford the most logical link to how such SHGs may have emerged within geological environments (Figure 2b) [48]. We have prepared SHGs using the method developed by Barge et al. [61], which affords hydrogels with moderate to good optical purity and gelation times that range over hours to seconds within the range of $0.5 \mathrm{M}$ silica to $1.0 \mathrm{M}$ silica, respectively. Critical-point drying provides samples of the silica matrix that have been subjected to scanning electron microscopy imaging. Secondary electron images of SHG matrices from $0.5 \mathrm{M}$ silica are shown in Figure 3. Figure 3a reveals a low magnification image (100 $\mu \mathrm{m}$ scale bar) of a rather fractured silica surface. Under higher magnification, the formation more closely resembles branching dendritic motifs ca 5-8 $\mu \mathrm{m}$ in length [65]. The morphologies that emerge are, however, dependent upon the preparation concentrations and subsequent matrix modifications employed. However, as shown in Figure 4 for a $1.0 \mathrm{M}$ silicate gel formulation, there is considerable salt formation (presumably sodium silicates, acetate and hydroxides) in addition to the silica matrix. Subsequent dialysis for a period of four days resulted in dissolution of the salts and retention of the silica matrix. Scanning electron microscopy of this, post-dialyzed, material identified both spherical [66] and alveoli silica formulations (Figure 4), the latter of which revealed a far more porous and open silica matrix than prior to dialysis (Figure 4a-d). In support of this, we find that, overall, BET surface areas of the silica matrices increase from ca $160 \mathrm{~m}^{2} / \mathrm{g}$ to ca $410 \mathrm{~m}^{2} / \mathrm{g}$ post-dialysis (see Supplementary Information) [67].
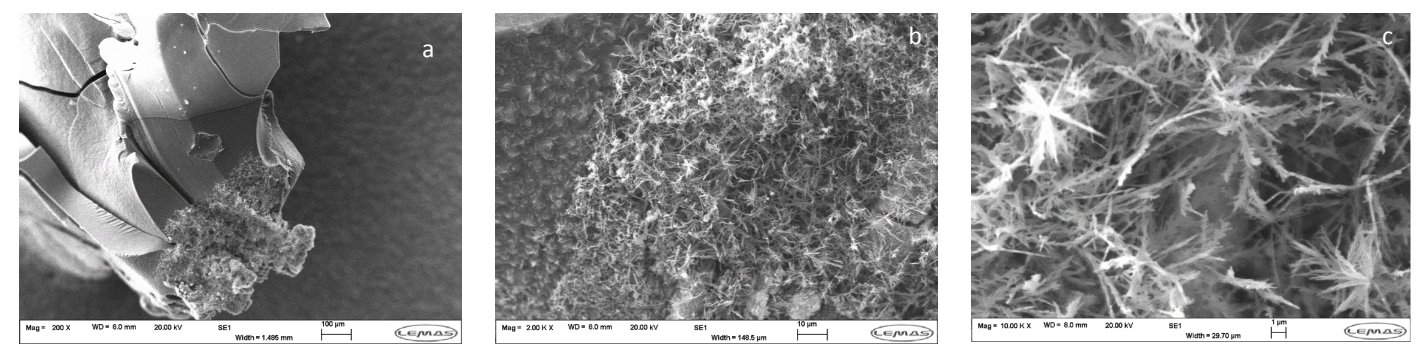

Figure 3. Secondary electron scanning electron microscope images of the solid mineral matrix of silica hydrogel (SHG) preparations, post-critical point drying; (a-c) low-to-high magnification images of matrix resulting from $0.5 \mathrm{M} \mathrm{SHG}$ (scale bars $100 \mu \mathrm{m}, 10 \mu \mathrm{m}, 1 \mu \mathrm{m}$, respectively). 

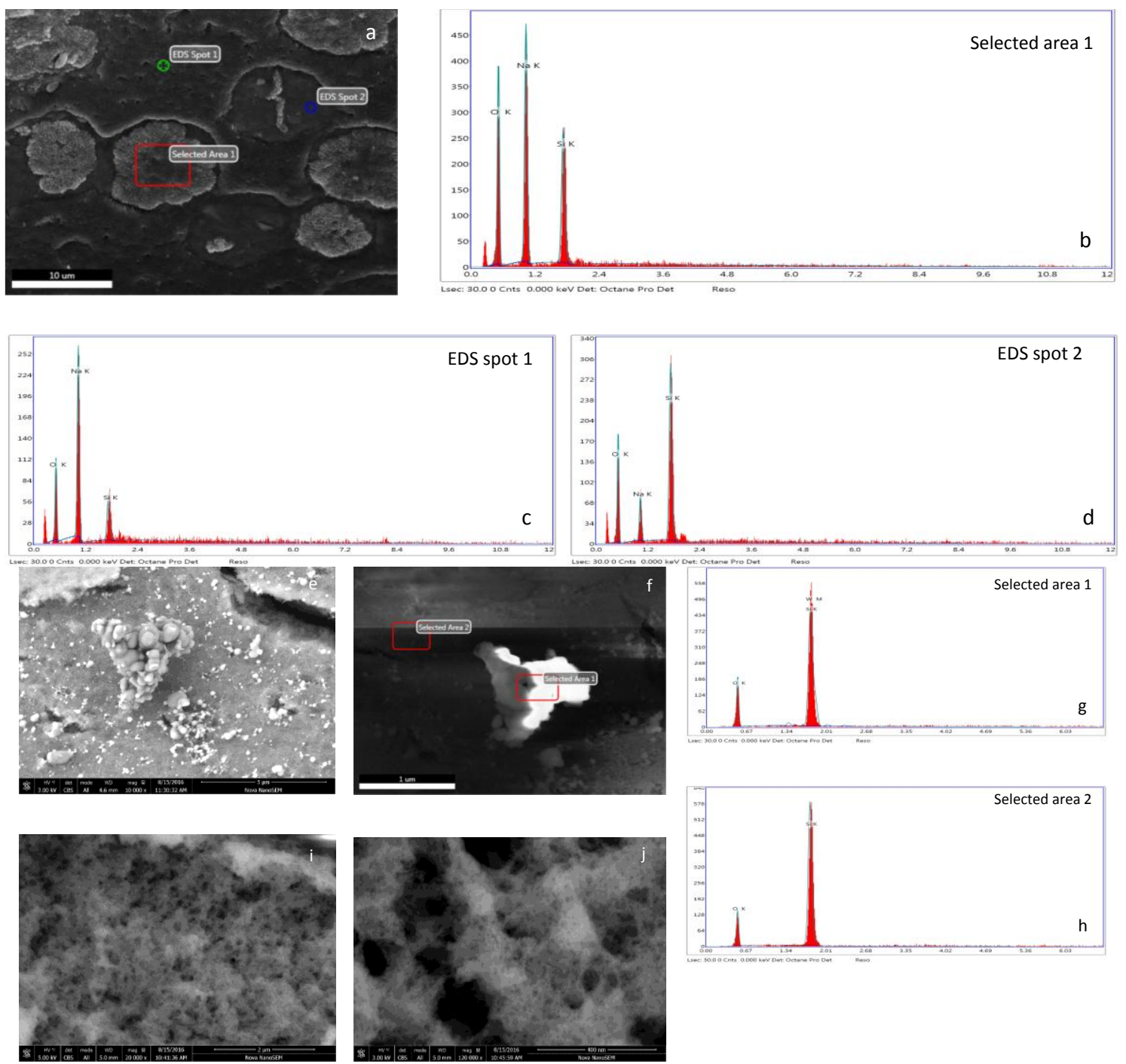

Figure 4. Scanning electron microscope images (secondary electron) of the solid mineral matrix of SHG preparations, post-critical point drying; matrix resulting from 1.0 M SHG. (a-d) reveals the presence of sodium salts in addition to silica; $(\mathbf{e}-\mathbf{h})$ illustrate spherical silica formation and $(\mathbf{i}, \mathbf{j})$ reveal the more open alveoli structure of the silica matrix.

We have also monitored the $\mathrm{pH}$ change in a representative SHG preparation (Figure $5 \mathrm{a}$; in this case with a $1.0 \mathrm{M}$ silica SHG), which demonstrates the graduate rise in $\mathrm{pH}$ as the silicate solution is added to the acid phase, inverted gently three times and then the $\mathrm{pH}$ probe inserted (see Section 2.2). The graph trends towards a plateau after some 45 min wherein the $\mathrm{pH}$ stabilizes within the 9-10 $\mathrm{pH}$ range. In addition, we have also monitored the evolution of particle size distribution, as a function of time, during the gelation period of these SHGs, using dynamic light-scattering (see Supplementary Materials for details). As such, the instrument was programmed to collect readings every $10 \mathrm{~min}$ for a total of $6 \mathrm{~h}$. The results (Figure $5 \mathrm{~b}$ ) reveal a steady increase in particle size in solution up to a maximum of ca $450 \mathrm{~nm}$ after ca $100 \mathrm{~min}$. Thereafter, there is a general drop-off to less than $100 \mathrm{~nm}$ after ca $180 \mathrm{~min}$, suggesting that aggregation of larger particulates had taken place. 


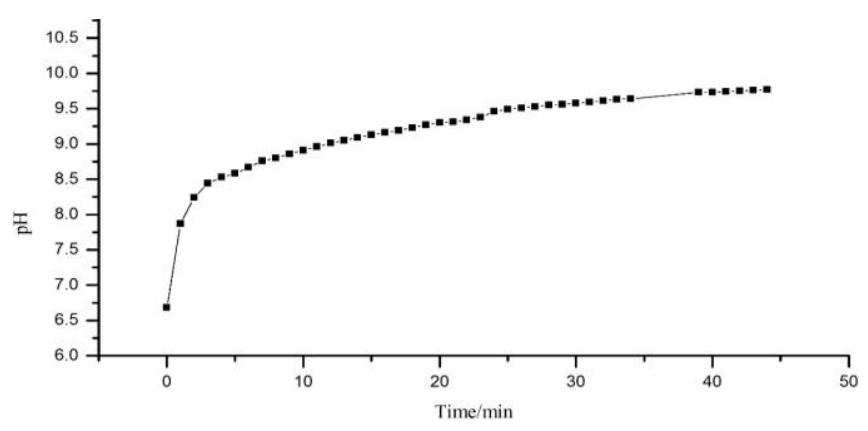

(a)

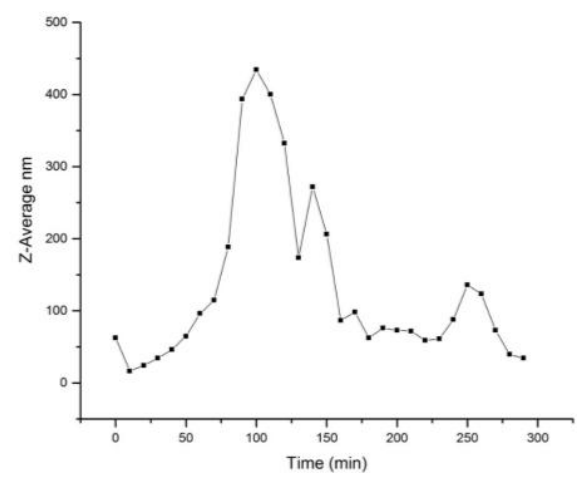

(b)

Figure 5. (a) $\mathrm{pH}$ change during gelation process of a $1.0 \mathrm{M} \mathrm{SHG}$ preparation (Jenway $350 \mathrm{pH}$ meter with $\mathrm{Ag} / \mathrm{AgCl}$ micro electrode); (b) particle size change as a function of time during monitoring of gelation in a $0.5 \mathrm{M} \mathrm{SHG}$ preparation via dynamic light-scattering (Malvern Zetasizer Nano ZSP).

\subsection{Coupling of Pi within the Silica Hydrogel Phase}

In 2008, we published an analysis of how the oxidative coupling of low oxidation state P-species, specifically phosphite $\left(\mathrm{H}_{2} \mathrm{PO}_{3}{ }^{-}\right)$and hypophosphite $\left(\mathrm{H}_{2} \mathrm{PO}_{2}{ }^{-}\right)$, could take place in the presence of (i) a Fenton reactor, a combination of ferrous ions [Fe(II)] and hydrogen peroxide; or (ii) ionizing radiation [68]. In that contribution, we recognised the importance of the solution phase to achieving coupling. In the present contribution, we have sought to explore related coupling protocols in (arguably) more geologically plausible conditions than an unadulterated aqueous phase. Thus, we have examined the ability of Pi species to undergo coupling in a silica hydrogel phase in the presence of metal salts, introduced to be either homogeneous or heterogeneous to the system. The experimental work-up procedure used (Section 2.3) meant that the coupling product that we were attempting to identify was pyrophosphate, $\mathrm{PPi}(\mathrm{V})$, as all other potential coupling products [pyrophosphite, $\mathrm{PPi}(\mathrm{III})$, isohypophosphate, $\mathrm{PPi}(\mathrm{III}-\mathrm{V})$ ], would be decomposed during the high $\mathrm{pH}$ work-up. The basic experimental gel system is described in Section 2.3 above, but variations were made to this composition according to the variables outlined in Table 1 below. Each combination of solvent, acid type, Pi components and metal additives was examined in a series of experiments that were reviewed for their ability to generate $\mathrm{PPi}(\mathrm{V})$ by ${ }^{31} \mathrm{P}-\mathrm{NMR}$ spectroscopy.

This sequence of experiments and their outcomes are collected in Table 2. From the results of these experiments (Table 2 entries G1-27 and control experiments C1-6), we were able to make the following observations:

(1) No Pi coupling was observed under any conditions where hydrochloric acid $(\mathrm{HCl})$ was used as the low $\mathrm{pH}$ component of the gel system.

(2) No metal additive, other than Fe(II), afforded any Pi coupling.

(3) Successful Pi coupling protocols using acetic acid also delivered positive results for Pi coupling when acetic was replaced by formic acid.

(4) No successful Pi coupling was observed when the Pi components were used seperately, $\mathrm{Pi}(\mathrm{III})$ or $\mathrm{Pi}(\mathrm{V})$.

(5) Successful Pi coupling was achieved only using a 1:1 mixture of $\mathrm{Pi}(\mathrm{III})$ and $\mathrm{Pi}(\mathrm{V})$ or pure $\mathrm{PPi}(\mathrm{III}-\mathrm{V})$.

(6) Successful Pi coupling was observed both when the Fe(II) additive used was employed either in solution or as a heterogeneous addition to the pre-formed gel.

(7) Successful Pi coupling was observed with Fe(II) only when formulated aerobically. No coupling was observed under anaerobic conditions.

(8) Control experiments performed under aqueous (non-gelled) conditions revealed no Pi coupling but distinct oxidation of $\mathrm{PPi}(\mathrm{III}-\mathrm{V})$ in the presence of Fe(II)-air [1.3\% conversion of PPi(III-V) to $\mathrm{PPi}(\mathrm{V})]$ and pronounced oxidation in the presence of the Fenton system, $\mathrm{Fe}(\mathrm{II})-\mathrm{H}_{2} \mathrm{O}_{2}[35.1 \%$ conversion of $\mathrm{PPi}(\mathrm{III}-\mathrm{V})$ to $\mathrm{PPi}(\mathrm{V})]$. 


\section{Discussion}

From these experiments we conclude that the following components are implicated in the formation of $\mathrm{PPi}(\mathrm{V})$ : (i) a mixture of $\mathrm{Pi}(\mathrm{III})$ and $\mathrm{Pi}(\mathrm{V})$ or pure $\mathrm{PPi}(\mathrm{III}-\mathrm{V})$; (ii) $\mathrm{Fe}(\mathrm{II})$; (iii) acetic or formic acid (not $\mathrm{HCl}$ ); (iv) aerobic conditions or the presence of $\mathrm{H}_{2} \mathrm{O}_{2}$ as an oxidant; and (v) the presence of a gel system and/or a high surface area mineral. The results from Table 2 reveal that the amounts of $\mathrm{PPi}(\mathrm{V})$ produced when the feed $\mathrm{Pi}$ components are $\mathrm{Pi}(\mathrm{III})$ and $\mathrm{Pi}(\mathrm{V})$ (1:1 mole equivalent) are very small, within the range $0.1-0.6 \%$ (entries G1-10, Table 2) regardless of conditions such as quantity of Fe(II) used (between $25 \mathrm{mg}-250 \mathrm{mg}$ ), or whether acetic or formic acid was used to gel the system (both formic and acetic acids produced $\mathrm{PPi}(\mathrm{V})$ with the same order of magnitude). However, significantly, we find that when $\mathrm{PPi}(\mathrm{III}-\mathrm{V})$ is used instead of $\mathrm{Pi}(\mathrm{III})$ and $\mathrm{Pi}(\mathrm{V})$, then $\mathrm{PPi}(\mathrm{V})$ was observed at $2-3 \%( \pm 1)$ when performed under aerobic conditions (see Figure 6 for an exemplar ${ }^{31} \mathrm{P}-\mathrm{NMR}$ spectrum of the product from reaction G14) which was still a small value overall, but nevertheless 6-10 times greater than was observed with the individual Pi components themselves. When $\mathrm{H}_{2} \mathrm{O}_{2}$ was substituted for air, it was observed that PPi(III-V) was converted to $\mathrm{PPi}(\mathrm{V})$ far more efficiently, as expected under such Fenton-like conditions (entries G13-18, Figure S2, Table 2 [67]); even removing the $\mathrm{Fe}(\mathrm{II})$ and employing $\mathrm{H}_{2} \mathrm{O}_{2}$ alone resulted in conversion of $\mathrm{PPi}(\mathrm{III}-\mathrm{V})$ to $\mathrm{PPi}(\mathrm{V})$ on the order of 1-2\% (entries G19-21). A series of control experiments was also performed (C1-C6; Table 2) under non-gelled, aqueous conditions, which revealed oxidation of $\mathrm{PPi}(\mathrm{III}-\mathrm{V})$ to $\mathrm{PPi}(\mathrm{V})$ at ca $1-2 \%$ under aerobic conditions ( $\mathrm{C} 2$ \& $\mathrm{C} 6$ ); a considerable jump then to $\mathrm{ca} 30 \%$ oxidation in the presence of $\mathrm{H}_{2} \mathrm{O}_{2}$ is observed (C3) and there is no evidence of Pi coupling when a mixture of $\mathrm{Pi}(\mathrm{III})$ and $\mathrm{Pi}(\mathrm{V})$ is used (C1, C4 \& C5).

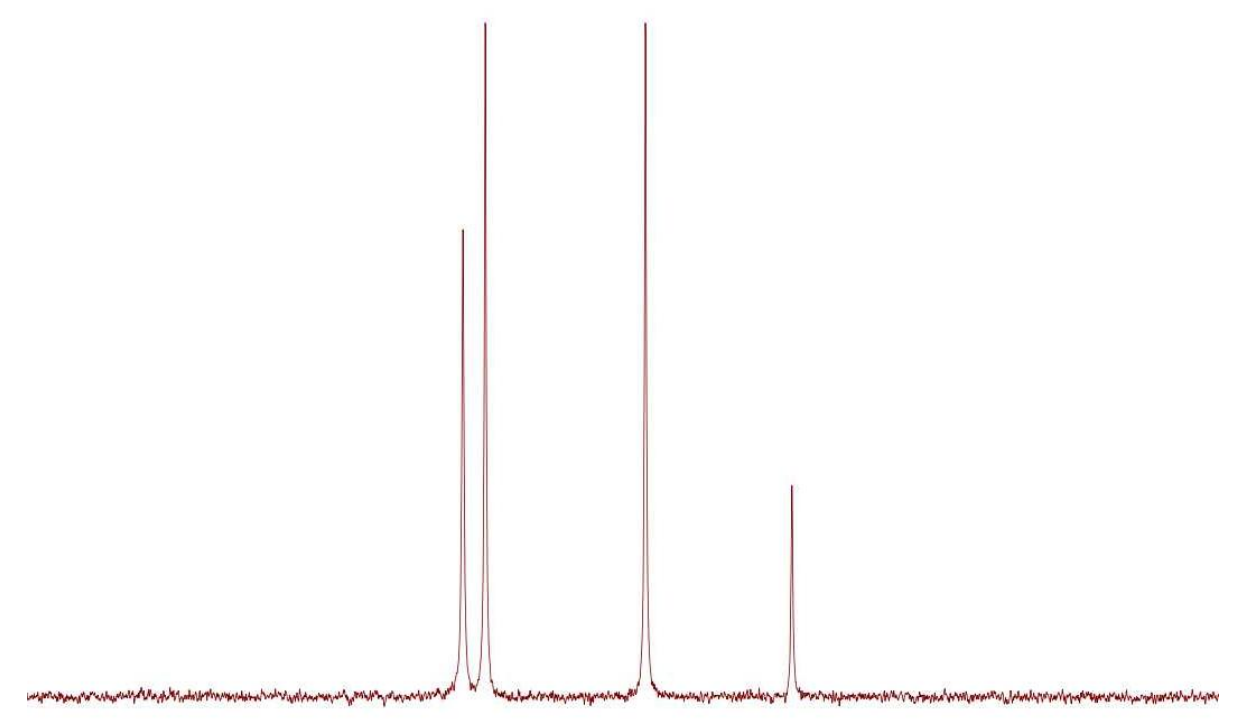

\begin{tabular}{lllllllllllllllllllllllllllllllllllllllllll}
\hline 9 & 18 & 17 & 16 & 15 & 14 & 13 & 12 & 11 & 10 & 9 & 8 & 7 & 6 & 5 & 4 & 3 & 2 & 1 & 0 & -1 & -2 & -3 & -4 & -5 & -6 & -7 & -8 & -9 & -10 & -11 & -12 & -13 & -14 & -15
\end{tabular}

Figure 6. Representative ${ }^{31} \mathrm{P}-\mathrm{NMR}$ spectrum demonstrating PPi(V) formation from entry G14 demonstrating the presence of $\operatorname{PPi}(\mathrm{V})$ in $9.4 \%$ of total $\mathrm{Pi}$ (signal at $\delta-3.1 \mathrm{ppm})$. The signals at $\delta+5.9$ and $\delta+1.1$ correspond to $\mathrm{Pi}(\mathrm{III})$ and that at $\delta+6.5 \mathrm{ppm}$ corresponds to $\mathrm{Pi}(\mathrm{V})$. Horizontal scale is chemical shift, $\delta$, in ppm.

On the basis of the data presented, therefore, we envisage a process within the presence of the silica hydrogel in which $\mathrm{Pi}(\mathrm{III})$ and $\mathrm{Pi}(\mathrm{V})$ undergo a condensation to afford $\mathrm{PPi}(\mathrm{III}-\mathrm{V})$ as an intermediary phase. This then undergoes Fe(II)-mediated oxidation via a Fenton-like reaction in a manner analogous to that reported by Pasek and Kee, in the aqueous phase [68]. That we do not see any intermediate $\mathrm{PPi}(\mathrm{III}-\mathrm{V})$ in our experiments is, we believe, a consequence of the high $\mathrm{pH}$ work-up 
procedure, which leads to rapid hydrolysis of isohypophosphate [69] (pyrophosphate is considerably more stable under such conditions). We speculate on two mechanistic possibilities for the primary in-gel Pi coupling. In one possibility, an $\mathrm{Fe}(\mathrm{II})-\mathrm{O}_{2}$ (air) mediated process leads to Pi radicals which combine to afford $\mathrm{PPi}(\mathrm{V})$ (Scheme 1a). In the second possibility, a reaction between acetic acid and Pi to afford acetylphosphorus species which subsequently engage in condensation to afford PPi(III-V), which then is oxidised by the Fe(II)-oxidant system to PPi(V) (Scheme 1b). Any oxidative pathway, such as that outlined in Scheme 1a, would most likely be mechanistically complex, as has already been demonstrated for the solution and mineral-supported $\mathrm{Fe}(\mathrm{II})-\mathrm{O}_{2}$ (air) redox system [70]. As we do not observe Pi coupling in the aqueous, non-gel phase in the presence of $\mathrm{Fe}(\mathrm{II})-\mathrm{O}_{2}$ (air) alone, any such oxidative coupling may then be a consequence of the environment changing from the aqueous to salt-gel phase; further studies are needed to explore this possibility. In the second alternative, outlined in Scheme $1 \mathrm{~b}$, an acetylphosphorus intermediate (1) is formed by reaction between Pi species and acetic acid, which subsequently undergoes condensation with Pi to afford PPi(III), PPi(III-V) or PPi(V), a process for which precedent exists [56]. Given that such a condensation between Pi and acetic acid would be significantly less likely in a high rather than low $\mathrm{pH}$ environment, we speculate that any formation of acetylphosphorus species is more likely to take place prior to the addition of silicate solution and hence gel formation. Furthermore, since our experiments seem to suggest that Pi coupling does not take place in the aqueous phase and that coupling within the gel requires also the presence of $\mathrm{Pi}(\mathrm{III})$, one might speculate that the presence of a silica matrix of high surface area within the high-pH (ca 9-10 $\mathrm{pH}$ units) gel phase is having some influence over the coupling process. The nature of such an effect would require further, more detailed mechanistic investigations which are currently on-going.

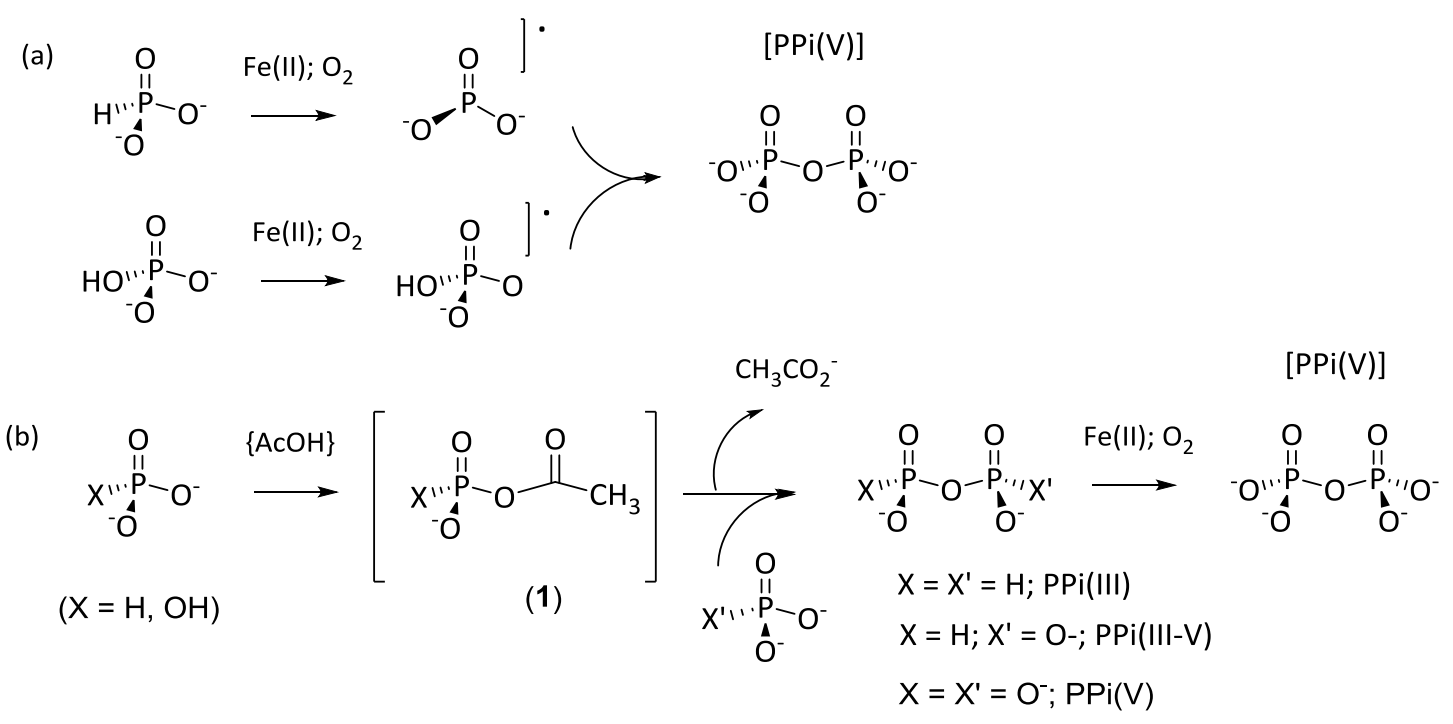

Scheme 1. Suggested possible pathway frameworks for $\mathrm{PPi}(\mathrm{V})$ production from $\mathrm{Pi}(\mathrm{III})$ and $\mathrm{Pi}(\mathrm{V})$ mixtures in Fe(II)-air based silica hydrogels. (a) Oxidative coupling pathway; and (b) condensation-oxidation pathway.

\section{Conclusions}

We have attempted here to demonstrate that metal-mediated coupling of phosphorus oxyacids (Pi) can occur under ambient temperature conditions, without additional condensation? Agents in environments that may be considered more geologically relevant than pure aqueous solutions. In so doing, we chose to examine such processes in geologically-relevant silica hydrogels [46-48], which have precedent as a substitute for a putative primitive cellular cytoplasm [31-35]. We find that the coupling of mixtures of $\mathrm{Pi}(\mathrm{III})$ and $\mathrm{Pi}(\mathrm{V})$ does take place, albeit in low overall conversions in these preliminary static experiments, leading to the observation of $\mathrm{PPi}(\mathrm{V})$. Interestingly, we observe that no such coupling takes place under the same conditions in aqueous (non-gel) control experiments. 
We do not yet have sufficient evidence that would allow us to propose a definitive mechanism for such coupling, but the weight of evidence to date leads us to favour a Pi-coupling process to afford PPi(III-V) combined with an Fe(II)-air mediated oxidation of this oxyacid ultimately to PPi(V).

Experiments to explore the mechanism of coupling are on-going as well as a wider examination of the effects of the silica hydrogel environment on other processes of relevance to prebiotic chemistry.

Supplementary Materials: The following are available online at www.mdpi.com/2075-1729/7/4/45/s1, Figure S1: ${ }^{31} \mathrm{P}-\mathrm{NMR}$ spectrum of a mixture of isohypophoshate [PPi(III-V)], $\mathrm{Pi}(\mathrm{III})$ and $\mathrm{Pi}(\mathrm{V})$ in the proportions [PPi(III-V)]-[Pi(III)/Pi(V)] in the relative proportions: 44-56\%, Figure S2: ${ }^{31} \mathrm{P}-\mathrm{NMR}$ spectrum of reaction G18 demonstrating the presence of $\mathrm{PPi}(\mathrm{V})$ in $9.4 \%$ of total $\mathrm{Pi}$ (signal at $\delta-5.3 \mathrm{ppm}$ ). Also included are BET surface area measurements, rationalisation of silica hydrogel nomenclature and synthesis details for isohypophosphate [PPi(III-V)].

Acknowledgments: We thank the University of Leeds and the Government of Iraq (KA) for their financial support for this work. In addition, we thank Martin Fuller (UoL, critical point drying), Alex Kulak (UoL, scanning electron microscopy and surface-area measurements), Algy Kazlauciunas (UoL, dynamic light-scattering) for their combined technical expertise, and Professor Frances Westall, Thomas Georgelin and Avinash vicholous Dass (Centre Biophysique Moléculaire, Orléans, France) for many fruitful discussions.

Author Contributions: T.P.K. and I.B.G. conceived and designed the experiments; K.A., P.M.S. and T.W.H. performed the experiments; all authors analyzed the data; and T.P.K. and I.B.G. wrote the paper.

Conflicts of Interest: The authors declare no conflict of interest.

\section{References}

1. Fitz, D.; Reiner, H.; Rode, B.M. Chemical evolution toward the origin of life. Pure Appl. Chem. 2007, 79, 2101-2117. [CrossRef]

2. Danger, G.; Plasson, R.; Pascal, R. Pathways for the formation and evolution of peptides in prebiotic environments. Chem. Soc. Rev. 2012, 41, 5416-5429. [CrossRef] [PubMed]

3. Danger, G.; Boiteau, L.; Cottet, H.; Pascal, R. The peptide formation mediated by cyanate revisited. $\mathrm{N}$-Carboxyanhydrides as accessible intermediates in the decomposition of $\mathrm{N}$-carbamoylamino acids. J. Am. Chem. Soc. 2006, 128, 7412-7413. [CrossRef] [PubMed]

4. Leman, L.; Orgel, L.; Ghadiri, M.R. Carbonyl sulfide-mediated prebiotic formation of peptide. Science 2004, 306, 283-286. [CrossRef] [PubMed]

5. Bujdak, J.; Rode, B.M. Preferential amino acid sequences in alumina-catalyzed peptide bond formation. J. Inorg. Biochem. 2002, 90, 1-7. [CrossRef]

6. Le Son, H.; Suwannachot, Y.; Bujdak, J.; Rode, B.M. Salt-induced peptide formation from amino acids in the presence of clays and related catalysts. Inorg. Chim. Acta 1998, 272, 89-94. [CrossRef]

7. Forsythe, J.G.; Yu, S.-S.; Mamajanov, I.; Grover, M.A.; Krishnamurthy, R.; Fernandez, F.M.; Hud, N. Ester-Mediated Amide Bond Formation Driven by Wet-Dry Cycles: A Possible Path to Polypeptides on the Prebiotic Earth. Angew. Chem. Int. Ed. 2015, 54, 9871-9875. [CrossRef] [PubMed]

8. Rodriguez-Garcia, M.; Surman, A.J.; Cooper, G.J.T.; Suarez-Marina, I.; Hosni, Z.; Lee, M.P.; Cronin, L. Formation of oligopeptides in high yield under simple programmable conditions. Nat. Commun. 2015, 6, 8385. [CrossRef] [PubMed]

9. Cafferty, B.J.; Fialho, D.M.; Khanam, J.K.; Krishnamurthy, R.; Hud, N.V. Spontaneous formation and base pairing of plausible prebiotic nucleotides in water. Nat. Commun. 2016, 7, 11328. [CrossRef] [PubMed]

10. Andersen, J.L.; Flamm, C.; Merkle, D.; Stadler, P.F. In silico Support for Eschenmoser's Glyoxylate Scenario. Israel J. Chem. 2015, 55, 919-933. [CrossRef]

11. Bowler, F.R.; Chan, C.K.W.; Duffy, C.D.; Gerland, B.; Islam, S.; Powner, M.W.; Sutherland, J.D.; Xu, J. Prebiotically plausible oligoribonucleotide ligation facilitated by chemoselective acetylation Common origins of RNA, protein and lipid precursors in a cyanosulfidic protometabolism. Nat. Chem. 2013, 5, 383-389. [CrossRef] [PubMed]

12. Patel, B.H.; Percivalle, C.; Ritson, D.J.; Duffy, C.D.; Sutherland, J.D. Common origins of RNA, protein and lipid precursors in a cyanosulfidic protometabolism. Nat. Chem. 2015, 7, 301-307.

13. Hernandez, A.R.; Piccirilli, J.A. Chemical origins of life. Prebiotic RNA unstuck. Nat. Chem. 2013, 5, 360-362. [CrossRef] [PubMed] 
14. Cozens, C.; Mutschler, H.; Nelson, G.M.; Houlihan, G.; Taylor, A.I.; Holliger, P. Enzymatic Synthesis of Nucleic Acids with Defined Regioisomeric 2'-5' Linkages. Angew. Chem. Int. Ed. Engl. 2015, 54, 15570-15573. [CrossRef] [PubMed]

15. Yeates, J.A.M.; Hilbe, C.; Zwick, M.; Nowak, M.A.; Lehman, N. Dynamics of prebiotic RNA reproduction illuminated by chemical game theory. Proc. Natl. Acad. Sci. USA 2016, 113, 5030-5035. [CrossRef] [PubMed]

16. Zwicker, D.; Seyboldt, R.; Weber, C.A.; Hyman, A.A.; Juelicher, F. Growth and division of active droplets: A model for protocells. Growth Phys. 2016, 1-28. [CrossRef]

17. Arai, N.; Yoshimoto, Y.; Yasuoka, K.; Ebisuzaki, T. Self-assembly behaviours of primitive and modern lipid membrane solutions: a coarse-grained molecular simulation study. Phys. Chem. Chem. Phys. 2016, 18, 19426-19432. [CrossRef] [PubMed]

18. Hanczyc, M.M.; Monnard, P.-A. The origin of life and the potential role of soaps. Lipid Technol. 2016, 28, 88-92. [CrossRef]

19. Saha, R.; Chen, I.A. Origin of Life: Protocells Red in Tooth and Claw. Curr. Biol. 2015, 25, R1175-R1177. [CrossRef] [PubMed]

20. Jia, T.Z.; Hentrich, C.; Szostak, J.W. Rapid RNA Exchange in Aqueous Two-Phase System and Coacervate Droplets. Orig. Life Evol. Biosph. 2014, 44, 1-12. [CrossRef] [PubMed]

21. Mulkidjanian, A.Y.; Makarova, K.S.; Galperin, M.Y.; Koonin, E.V. Inventing the dynamo machine: The evolution of the F-type and V-type ATPases. Nat. Rev. Microbiol. 2007, 5, 893-899. [CrossRef] [PubMed]

22. Herschy, B.; Whicher, A.; Camprubi, E.; Watson, C.; Dartnell, L.; Ward, J.; Evans, J.R.G.; Lane, N. An Origin-of Life Reactor to Simulate Alkaline Hydrothermal Vents. J. Mol. Evol. 2014, 79, 213-227. [CrossRef] [PubMed]

23. Barge, L.M.; Kee, T.P.; Doloboff, I.J.; Hampton, J.M.P.; Ismail, M.; Pourkashanian, M.; Zeytounian, J.; Baum, M.M.; Moss, J.A.; Lin, C.-K.; et al. The Fuel Cell Model of Abiogenesis: A New Approach to Origin-of-Life Simulations. Astrobiology 2014, 14, 254-270. [CrossRef] [PubMed]

24. Barge, L.M.; Doloboff, I.J.; Russell, M.J.; Vander Velde, D.; White, L.M.; Stucky, G.D.; Baum, M.M.; Zeytounian, J.; Kidd, R.; Kanik, I. Pyrophosphate synthesis in iron mineral films and membranes simulating prebiotic submarine hydrothermal precipitates. Geochim. Cosmochim. Acta 2014, 128, 1-12. [CrossRef]

25. Barge, L.M.; Branscomb, E.; Brucato, J.R.; Cardoso, S.S.; Cartwright, J.H.E.; Danielache, O.; Galante, D.; Kee, T.P.; Miguel, Y.; Mojzsis, S.; et al. Thermodynamics, Disequilibrium, Evolution: Far-From-Equilibrium Geological and Chemical Considerations for Origin-Of-Life Research. Orig. Life Evol. Biosph. 2017, 47, $39-56$. [CrossRef] [PubMed]

26. Stevenson, A.; Burkhardt, J.; Cockell, C.S.; Cray, J.A.; Dijksterhuis, J.; Fox-Powell, M.; Kee, T.P.; Kminek, G.; McGenity, T.J.; Timmis, K.N.; et al. Multiplication of microbes below 0.690 water activity: Implications for terrestrial and extraterrestrial life. Environ. Microbiol. 2015, 17, 257-277. [CrossRef] [PubMed]

27. Cape, J.L.; Monnard, P.-A.; Boncella, J.M. Prebiotically relevant mixed fatty acid vesicles support anionic solute encapsulation and photochemically catalyzed trans-membrane charge transport. Chem. Sci. 2011, 2, 661-671. [CrossRef]

28. Georgelin, T.; Jaber, M.; Bazzi, H.; Lambert, J.-F. Formation of Activated Biomolecules by Condensation on Mineral Surfaces-A Comparison of Peptide Bond Formation and Phosphate Condensation. Orig. Life Evol. Biosph. 2014, 43, 429-443. [CrossRef] [PubMed]

29. Mutschler, H.; Wochner, A.; Holliger, P. Freeze-thaw cycles as drivers of complex ribozyme assembly. Nat. Chem. 2015, 7, 502-508. [CrossRef] [PubMed]

30. Dass, A.V.; Hickman-Lewis, K.; Brack, A.; Kee, T.P.; Westall, F. Stochastic prebiotic chemistry within realistic geological systems. ChemistrySelect 2016, 1, 4906-4926. [CrossRef]

31. Trevors, J.T.; Gerald, H.; Pollack, G.H. Hypothesis: The origin of life in a hydrogel environment. Prog. Biophys. Mol. Biol. 2005, 89, 1-8. [CrossRef] [PubMed]

32. Trevors, J.T. Perspective: Researching the transition from non-living to the first microorganisms: Methods and experiments are major challenges. J. Microbiol. Methods 2010, 81, 259-263. [CrossRef] [PubMed]

33. Trevors, J.T. Origin of microbial life: Nano- and molecular events, thermodynamics/entropy, quantum mechanisms and genetic instructions. J. Microbiol. Methods 2011, 84, 492-495. [CrossRef] [PubMed]

34. Trevors, J.T. Hypothesized origin of microbial life in a prebiotic gel and the transition to a living biofilm and microbial mats. Comptes Rendus Biol. 2011, 334, 269-272. [CrossRef] [PubMed]

35. Pollack, G.H. Cells, Gels and the Engines of Life; Ebner and Sons: Seattle, WA, USA, 2001; ISBN 13:978-0962689529. 
36. Yang, D.; Peng, S.; Hartman, M.R.; Gupton-Campolongo, T.; Rice, E.J.; Chang, A.K.; Gu, Z.; Lu, G.Q.; Luo, D. Enhanced transcription and translation in clay hydrogel and implications for early life evolution. Sci. Rep. 2013, 3, 1-6. [CrossRef] [PubMed]

37. Weiss, M.C.; Sousa, F.L.; Mrnjavac, N.; Neukirchen, S.; Roettger, M.; Nelson-Sathi, S.; Martin, W.F. The physiology and habitat of the last universal common ancestor. Nat. Microbiol. 2016, 1, 1-8. [CrossRef] [PubMed]

38. Kee, T.P.; Monnard, P.-A. On the Emergence of a Proto-Metabolism and the Assembly of Early Protocells. Elements 2016, 12, 419-424. [CrossRef]

39. Santiburcio, D.M.; Marx, D. Chemistry in nano-confined water. Chem. Sci. 2017, 8, 3444-3452. [CrossRef] [PubMed]

40. Hansma, H.G. Better than Membranes at the Origin of Life? Life 2017, 7, 28. [CrossRef] [PubMed]

41. Saha, R.; Pohorille, A.; Chen, I.A. Molecular Crowding and Early Evolution. Orig. Life Evol. Biosph. 2014, 44, 319-324. [CrossRef] [PubMed]

42. Oparin, A.I.; Serebrovskaia, K.B.; Vasileva, N.V.; Balaevsk, T.O. Formation of coacervates from polypeptides and polynucleotides. Dokl. Akad. Nauk. 1961, 154, 407-412.

43. Fox, W. The evolutionary significance of phase-separated microsystems. Orig. Life Evol. Biosph. 1976, 7, 49-68. [CrossRef]

44. Mann, S. The origins of life: Old problems, new chemistries. Angew. Chem. 2013, 52, 155-162. [CrossRef] [PubMed]

45. Copley, S.D.; Smith, E.; Morowitz, H.J. The origin of RNA world: Co-evolution of genes and metabolism. Bioorg. Chem. 2007, 35, 430-443. [CrossRef] [PubMed]

46. Grenne, T.; Slack, J.F. Bedded jaspers of the Ordovician Løkken ophiolite, Norway: Seafloor deposition and diagenetic maturation of hydrothermal plume-derived silica-iron gels. Miner. Deposita 2003, 38, 625-639. [CrossRef]

47. Papineau, D. Mineral Environments on the Early Earth. Elements 2010, 6, 25-30. [CrossRef]

48. Kirkpatrick, J.D.; Rowe, C.D.; White, J.C.; Brodsky, E.E. Silica gel formation during fault slip: Evidence from the rock record. Geology 2013. [CrossRef]

49. Serrano, A.; Perez-Castineira, J.R.; Baltscheffsky, H.; Baltscheffsky, M. Proton-Pumping Inorganic Pyrophosphatases in Some Archaea and Other Extremophilic Prokaryotes. J. Bioenergy Biomembr. 2004, 36, 127-133. [CrossRef]

50. Serrano, A.; Perez-Castineira, J.R.; Baltscheffsky, M.; Baltscheffsky, H. H+-PPases: Yesterday, today and tomorrow. Int. Union Biochem. Mol. Biol. 2007, 59, 76-83. [CrossRef] [PubMed]

51. Baltscheffsky, M.; Schultz, A.; Baltscheffsky, H. $\mathrm{H}^{+}$-proton-pumping inorganic pyrophosphatase: A tightly membrane-bound family. FEBS Lett. 1999, 452, 121-127. [CrossRef]

52. Feng, N.; Sun, S.; Chao, H.; Zhao, Y. N-phosphorylation of amino acids by trimetaphosphate in aqueous solution-Learning from prebiotic synthesis. Green Chem. 2009, 11, 569-573.

53. Cheng, C.; Fan, C.; Wan, R.; Tong, C.; Miao, Z.; Chen, J.; Zhao, Y. Phosphorylation of adenosine with trimetaphosphate under simulated prebiotic conditions. Orig. Life Evol. Biosph. 2002, 32, 219-224. [CrossRef] [PubMed]

54. Ozawa, K.; Nemoto, A.; Imai, E.-I.; Honda, H.; Hatori, K.; Matsuno, K. Phosphorylation of nucleotide molecules in hydrothermal environments. Orig. Life Evol. Biosph. 2004, 34, 465-471. [CrossRef] [PubMed]

55. Bryant, D.E.; Greenfield, D.; Walshaw, R.D.; Johnson, B.R.G.; Herschy, B.; Smith, C.; Pasek, M.A.; Telford, R.; Scowen, I.; Munshi, T.; et al. Hydrothermal modification of the Sikhote-Alin iron meteorite under low $\mathrm{pH}$ geothermal environments. A plausibly prebiotic route to activated phosphorus on the early Earth. Geochim. Cosmochim. Acta 2013, 109, 90-112. [CrossRef]

56. Bryant, D.E.; Herschy, B.; Marriott, K.E.R.; Cosgrove, N.E.; Pasek, M.A.; Atlas, Z.D.; Cousins, C.R.; Kee, T.P. Phosphate Activation via Reduced Oxidation State Phosphorus (P). Mild Routes to Condensed-P Energy Currency Molecules. Life 2013, 3, 386-402.

57. Kaye, K.; Bryant, D.E.; Marriott, K.E.R.; Fishwick, C.W.G.; Kee, T.P. Selective phosphonylation of 5'-adenosine monophosphate (5'-AMP) via pyrophosphate [PPi(III)]. Orig. Life Evol. Biosph. 2016, 46, 425-434. [CrossRef] [PubMed]

58. Madhurambal, G.; Subha, R.; Mojumdar, S.C. Crystallization and thermal characterization of calcium hydrogen phosphate dihydrate crystals. J. Therm. Anal. Calorim. 2009, 96, 73-76. [CrossRef] 
59. Steinman, G.; Kenyon, D.H.; Calvin, M. Dehydration condensation in aqueous solution. Nature 1965, 206, 707-708. [CrossRef]

60. Pasek, M.A.; Kee, T.P. On the Origin of Phosphorylated Biomolecules. In Origins of Life: The Primal Self-Organization; Egel, R., Ed.; Springer: Berlin/Heidelberg, Germany, 2011.

61. Barge, L.; Hammond, D.; Chan, M.; Potter, S.; Petruska, J.; Nealson, K. Precipitation patterns formed by self-organizing processes in porous media. Geofluids 2011, 11, 124-133. [CrossRef]

62. ASTM D1141: Standard Specification for Substitute Ocean Water. Available online: https: / /global.ihs.com/doc_detail.cfm?\&input_doc_number=\&input_doc_title=\&document_name=ASTM\% 20D1141\&item_s_key=00015449\&item_key_date=070131\&origin=DSSC (accessed on 3 November 2017).

63. Ahmed, E.M. Hydrogel: Preparation, characterization, and applications: A review. J. Adv. Res. 2015, 6, 105-121. [CrossRef] [PubMed]

64. Cammarata, M.; Caronna, C.; Fiandaca, G.; Levantino, M.; Schir, G.; Vitrano, E.; Cupane, A. Water and Proteins confined in Silica Hydrogels and Silica Nanoparticles: Structural, Dynamic and Functional Studies. In Proceedings of the Progress in Condensed Matter Physics: Festschrift in Honour of Vincenzo Grasso, Messina, Mexico, 9 January 2003; pp. 139-152.

65. Hu, X.; Wang, X.; Liu, J.; Zhang, S.; Jiang, C.; He, X. Fabrication of mesoporous dendritic silica nanofibers by using dendritic polyaniline templates. Mater. Chem. Phys. 2012, 137, 17-21. [CrossRef]

66. Alkimim, I.P.; Silva, L.L.; Cardoso, D. Synthesis of hybrid spherical silicas and application in catalytic transesterification reaction. Microporous Mesoporous Mater. 2017. [CrossRef]

67. Christy, A.A. Quantitative determination of surface area of silica gel particles by near infrared spectroscopy and chemometrics. Physicochem. Eng. Asp. 2008, 3221, 248-252. [CrossRef]

68. Pasek, M.A.; Kee, T.P.; Bryant, D.E.; Pavlov, A.A.; Lunine, J.L. Production of Potentially Prebiotic Condensed Phosphates by Phosphorus Redox Chemistry. Angew. Chem. Int. Ed. 2008, 47, 7918-7920. [CrossRef] [PubMed]

69. Mistry, D.; Powles, N. The relative hydrolytic reactivities of pyrophosphites and pyrophosphates. Org. Biomol. Chem. 2013, 11, 5727-5733. [CrossRef] [PubMed]

70. Burke, S.P.; Banwart, S.A. A geochemical model for removal of iron(II)(aq) from mine water discharges. Appl. Geochem. 2002, 17, 431-443. [CrossRef]

(C) 2017 by the authors. Licensee MDPI, Basel, Switzerland. This article is an open access article distributed under the terms and conditions of the Creative Commons Attribution (CC BY) license (http:/ / creativecommons.org/licenses/by/4.0/). 